\title{
Different proteomic profiles of sweet whey and rennet casein obtained after preparation from raw versus heat-treated skimmed milk
}

\author{
Lotte Bach Larsen $^{1 *}$, Anna Wedholm-Pallas ${ }^{2}$, \\ Helena LindMARK-MÅnsson ${ }^{3}$, Anders ANDRÉN ${ }^{2}$ \\ ${ }^{1}$ Department of Food Science, Faculty of Agricultural Sciences, Aarhus University, \\ DK-8830 Tjele, Denmark \\ ${ }^{2}$ Department of Food Science, Uppsala BioCenter, Swedish University of Agricultural Sciences, \\ SE-750 07 Uppsala, Sweden \\ ${ }^{3}$ Swedish Dairy Association, SE-223 70 Lund, Sweden
}

Received 18 September 2009 - Revised 27 February 2010 - Accepted 29 April 2010

Published online 18 June 2010

\begin{abstract}
Proteomic profiles of sweet whey and rennet casein fractions prepared from raw or pasteurised $\left(72{ }^{\circ} \mathrm{C}\right.$ for $15 \mathrm{~s}$ ), skimmed milk were studied by proteomics coupled with the detection of protein spots by MALDI TOF mass spectrometry. Proteins were analysed by a modification of the traditional, two-dimensional gel electrophoresis (2-DGE) method under non-reducing running conditions, which potentially permits the visualisation of disulphide-linked protein complexes formed in response to pasteurisation. Separated proteins were stained with Coomassie blue. The relative spot volumes obtained after 2-DGE of fractions from raw or pasteurised milk were compared. A number of different spots in the rennet casein and sweet whey fractions were found to vary in response to pasteurisation. Some of these represented higher molecular mass complexes that increased in the chymosin-precipitated casein fraction, and they were identified by mass spectrometry to contain $\alpha_{\mathrm{S} 1}$-casein. Certain fragments of $\alpha_{\mathrm{S} 1}$-casein, probably generated as a result of chymosin cleavage, increased in the whey after pasteurisation. The whey content of proteose peptone component 3 (PP3) or lactophorin decreased after pasteurisation, which could indicate increased association of PP3 with for example the milk fat globule membrane after pasteurisation. This shows that gel-based proteome analysis can be used in the characterisation of subtle variations in protein composition of milk fractions that occur as a consequence of pasteurisation.
\end{abstract}

proteome analysis / sweet whey / rennet casein / pasteurisation

摘要 - 鲜奶和热处理脱脂乳制备的甜乳清和酶凝酪蛋白的蛋白质组学。以鲜奶和巴氏杀菌 $\left(72{ }^{\circ} \mathrm{C}, 15 \mathrm{~s}\right)$ 脱脂乳为原料制备甜乳清和酶凝酪蛋白, 采用蛋白质组学结合 MALDI TOF 质谱检测方法, 研究了上述组分的蛋白质组表达谱。采用改进的传统二维凝胶电泳 (2-DGE) 方法, 在非还原条件下分析蛋白质。该方法可以呈现出由于杀菌过程中形成的以二硫键 连接的蛋白复合物。将分离获得的蛋白质采用考马斯亮蓝进行染色。比较了源于鲜奶和 巴氏杀菌脱脂乳的不同蛋白质组分在 2-DGE 上的相对斑点量。甜乳清和酶凝酪蛋白组 分对杀菌的反应不同, 产生了大量的差异蛋白斑点。在酶凝酪蛋白组分中, 较高分子量

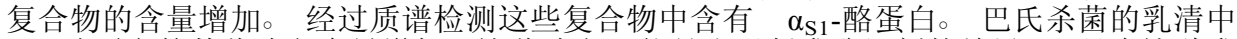

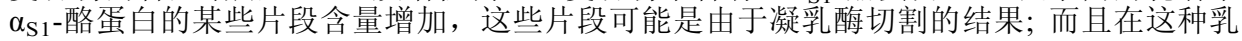

*Corresponding author (通讯作者): LotteBach.Larsen@agrsci.dk 
清中 PP3 和乳多肽的含量降低。这表明杀菌后, PP3 与脂肪球膜的结合增加了。研究表 明以凝胶为基础的蛋白质组分析能用于测定杀菌后乳蛋白组分的变化。

\title{
蛋白质组分析 / 甜乳清 / 酶凝酪蛋白 / 巴杀菌
}

\begin{abstract}
Résumé - Différents profils protéomiques obtenus à partir de lactosérum doux et de caséine présure issus de laits écrémés crus ou traités thermiquement. Les profils protéomiques de fractions obtenus à partir de lactosérum doux et de caséine présure de lait écrémé cru ou pasteurisé $\left(72{ }^{\circ} \mathrm{C}, 15 \mathrm{~s}\right)$ ont été étudiés par des analyses protéomiques couplées à une détection des spots protéiques par spectrométrie de masse MALDI TOF. Les protéines ont été analysées par électrophorèse sur gel bidimensionnelle (EG-2D) avec une modification de la méthode classique, sous conditions non réductrices, permettant la visualisation des complexes de protéines liées par ponts disulphure formés en réponse à la pasteurisation. Les protéines séparées étaient colorées au bleu de Coomassie. Les volumes relatifs des spots obtenus après EG-2D des fractions obtenues à partir de lait cru ou pasteurisé ont été comparés. Un nombre de spots différents était trouvé dans les fractions de caséine présure et de lactosérum doux en réponse à la pasteurisation. Certains spots représentaient des complexes de masse moléculaire plus élevée qui augmentaient dans la fraction de caséine obtenue par précipitation due à la chymosine et qui contenaient des caséines alpha S1 identifiées par spectrométrie de masse. Certains fragments de caséine alpha S1, probablement obtenus après clivage par la chymosine, augmentaient dans le lactosérum après pasteurisation. La teneur du lactosérum en composant 3 de la protéose peptone (PP3) ou lactophorine diminuait après pasteurisation, ce qui pourrait indiquer une association plus importante après pasteurisation du PP3 avec, par exemple, la membrane des globules gras. Cette étude montre que l'analyse protéomique sur gel peut être utilisée dans la caractérisation des variations subtiles dans la composition protéique des fractions laitières survenant après pasteurisation.
\end{abstract}

analyse protéomique / lactosérum doux / caséine présure / pasteurisation

\section{INTRODUCTION}

Heat treatment is involved in most milk processes to control microbial growth and sometimes also to fulfil a technological purpose. The functional properties of acid gel products, such as yoghurt and sour milk, are improved if the milk is heat-treated at $90{ }^{\circ} \mathrm{C}$ for $5 \mathrm{~min}$ due to the resulting complex binding between denatured $\beta$-lactoglobulin (LG) and $\kappa$-casein $(\mathrm{CN})$. For cheese milk, on the other hand, a too severe heat treatment will be a disadvantage due to these complexes, because $\kappa-\mathrm{CN}$ becomes less available for cleavage by chymosin. Much work has been carried out examining the effect of higher temperature heat treatments $\left(>90{ }^{\circ} \mathrm{C}\right)$ on milk protein composition, whereas less is known about the effect of low temperature, short time (LTST, $72-75^{\circ} \mathrm{C}$ for $15-30 \mathrm{~s}$ ) pasteurisation. The whey protein denaturation is initiated at temperatures higher than $60{ }^{\circ} \mathrm{C}$ [30]. The exact denaturation temperatures are conflicting depending on measuring conditions, but it has been suggested that $\alpha$-lactalbumin (LA) is unfolded at $63-67{ }^{\circ} \mathrm{C}$ and $\beta$-LG at 74-77 ${ }^{\circ} \mathrm{C}[5,24]$. The heat stabilities of $\alpha_{\mathrm{S}^{-}}$and $\beta$-CNs have been evaluated in earlier studies [19, 25]. It was shown that $\alpha_{\mathrm{S} 1-\mathrm{CN}}$ was relatively thermostable at temperatures up to $70{ }^{\circ} \mathrm{C}$ [19], and only small changes in the secondary structure of $\beta-\mathrm{CN}$ were observed above $50{ }^{\circ} \mathrm{C}$ [25]. Generally, at constant duration of the heat treatment, the denaturation of whey proteins increases with temperature in the range of $70-95^{\circ} \mathrm{C}[6]$, but still only limited changes will be expected at short time, low temperature pasteurisations.

During cheese making, when adding chymosin to milk, the casein profile is 
altered in several ways. In addition to the cleavage of $\kappa-\mathrm{CN}$ into para- $\kappa-\mathrm{CN}$ and caseinomacropeptide (CMP), it has also been demonstrated that chymosin has a proteolytic action on $\alpha_{\mathrm{S}^{-}}$and $\alpha_{\mathrm{S} 2}-\mathrm{CNs}[20,21]$, as well as on $\beta$-casein [10]. In addition to studying the effect of short time pasteurisation on milk protein composition, it would also be interesting to separate and identify chymosin-produced cleavage products in milk by use of proteome analysis. Previously, proteome analysis based on 2-DGE separation and mass spectrometry (MS) detection has been applied for the analysis of milk proteins, e.g. in the acid whey fraction [7] and in chymosin-separated whey and casein fractions using silver staining [32]. However, the method has great potential in the characterisation of a wide variety of different milk or cheese samples [23]. Recently, a proteomic study using combinations of reducing and non-reducing conditions was reported on changes in milk introduced as a result of heat treatment at $90{ }^{\circ} \mathrm{C}$ for up to $30 \mathrm{~min}[3]$.

The aim of the present study was to use 2-DGE-based proteomics for characterisation of the composition of chymosin-separated casein and sweet whey fractions prepared from raw and pasteurised milk. In order to study the usefulness of the method for the eventual visualisation and characterisation of disulphide-bonded complexes, a 2-DGE system at non-reducing conditions using Coomassie blue staining was applied. Furthermore, the aim was to use MS for the identification of proteins in the studied milk fractions.

\section{MATERIALS AND METHODS}

\subsection{Milk samples}

Evening whole milk samples from six individual SDM Holstein-Friesian cows were obtained from the experimental dairy herd at the Faculty of Agricultural
Sciences, Aarhus University at Research Centre Foulum, as described earlier [31], and used for further processing. The cows were in mid- to-late lactation (lactation week 19-48) and in lactation numbers 1-4. The total protein content of the samples was determined by Milkoscan FT 6000 (Foss Electric, Hillerød, Denmark) at Eurofins Laboratories (Holstebro, Denmark) and was found to be in the interval of $3.40-4.13 \mathrm{~g} \cdot \mathrm{L}^{-1}$. The cell counts were determined by Fossomatic (Foss Electric) at Eurofins Laboratories and were between 30000 and 251000 cells $\cdot \mathrm{mL}^{-1}$.

\subsection{Milk processing and sample fractionation}

After two days of cold storage $\left(4^{\circ} \mathrm{C}\right)$, aliquots of the milk samples of the individual cow's milk samples were preheated to $40{ }^{\circ} \mathrm{C}$, defatted and then heated in a pilot plate heating apparatus $\left(72{ }^{\circ} \mathrm{C}\right.$ for $\left.15 \mathrm{~s}\right)$, as described earlier [1]. The flow rate of milk through the system was approximately $1 \mathrm{~L} \cdot \mathrm{s}^{-1}$. Sample volumes of $5 \mathrm{~L}$ were used. The average time for the temperature to rise from 40 to $72{ }^{\circ} \mathrm{C}$ was $15 \mathrm{~s}$, after which the milk was held at $72{ }^{\circ} \mathrm{C}$ for $15 \mathrm{~s}$. Cold water $\left(9-9.5^{\circ} \mathrm{C}\right)$ was used in the second heat exchanger for cooling the heated milk (from 72 to $20^{\circ} \mathrm{C}$ in $4 \mathrm{~s}$ ). The milk was placed in a fridge and kept at $4{ }^{\circ} \mathrm{C}$ for $48 \mathrm{~h}$ before further treatment. Aliquots of both raw and heat-treated, skimmed milk samples were preheated at $30{ }^{\circ} \mathrm{C}$ for $30 \mathrm{~min}$, and fractionated into casein and whey by addition of chymosin $\left(2 \mathrm{~mL} \cdot \mathrm{L}^{-1}\right.$, Chy-Max Plus, 190 IMCU $\mathrm{mL}^{-1}$, Christian Hansen $\mathrm{A} / \mathrm{S}$, Hørsholm, Denmark). The samples were incubated at $30{ }^{\circ} \mathrm{C}$ for $30 \mathrm{~min}$ and then centrifuged at $1000 \times \mathrm{g}$ for $10 \mathrm{~min}$ at $5{ }^{\circ} \mathrm{C}$ to separate whey proteins and rennet casein fraction. The whey fraction was recovered, and the rennet casein fraction was washed twice in cold Millipore water (USF Elga Maxima system, Bucks, UK) and centrifuged at $1000 \times g$ for 5 min at $5{ }^{\circ} \mathrm{C}$. 
The rennet casein was finally dissolved in $0.1 \mathrm{~mol} \cdot \mathrm{L}^{-1}$ trisodium citrate buffer, $\mathrm{pH} 8.9$, to original milk volume and stored at $-20{ }^{\circ} \mathrm{C}$ until further use.

\subsection{Two-dimensional gel electrophoresis}

The whey and casein fractions were analysed separately by 2 -DGE. The casein samples were analysed using either reducing or non-reducing conditions in both dimensions, while the whey protein samples were analysed at non-reducing conditions only. A total of 36 gels was analysed consisting of four different gel sets: (1) Chymosin-precipitated casein from raw (six gels) or heattreated (six gels), skimmed milk analysed at non-reducing conditions in both dimensions, (2) whey prepared from raw (six gels) or heat-treated (six gels), skimmed milk analysed at non-reducing conditions in both dimensions, (3) chymosin-precipitated casein from heat-treated (six gels), skimmed milk analysed at reducing conditions in both dimensions and (4) sweet whey from heattreated (six gels), skimmed milk analysed at reducing conditions in both dimensions. All gel replicates represented true biological replicates of individually processed milk samples from the six individual cows in the experiment. For the non-reducing gels, the reducing agent, dithioerythritol (DTE), was omitted from the buffers used at the respective steps in the procedure. The first dimension of protein separation was carried out in immobilised $11 \mathrm{~cm}$ IPG strips (pH 4-7), whereas $7.5 \times 11 \mathrm{~cm} \mathrm{8-16 \%} \mathrm{gra-}$ dient Criterion gels were used for the second dimension (BioRad, Hercules, USA). A volume $(185 \mu \mathrm{L})$ corresponding to $150 \mu \mathrm{g}$ whey protein sample or $50 \mu \mathrm{g}$ caseins was applied to each gel. The total protein and whey protein contents were based on the Milkoscan determinations. The chosen amount of sample was dissolved at $1: 10 \mathrm{v} / \mathrm{v}$ in denaturing buffer $\left(40 \mathrm{mmol} \cdot \mathrm{L}^{-1}\right.$ Tris, $6 \mathrm{~mol} \cdot \mathrm{L}^{-1}$ urea, $2 \mathrm{~mol} \cdot \mathrm{L}^{-1}$ thiourea,
$1.5 \%(\mathrm{w} / \mathrm{v})$ pharmalyte; GE Healthcare, Uppsala, Sweden, 0.8\% (w/v) CHAPS; Applichem, Darmstadt, Germany, pH 7.5), with or without $1 \%(\mathrm{w} / \mathrm{v}) \mathrm{DTE}$, and incubated for $2 \mathrm{~h}$ at room temperature. The samples were then further diluted in a rehydration buffer to a final volume of $185 \mu \mathrm{L}$. The rehydration buffer consisted of the same substrates, in same concentrations as the above, but with pharmalyte $\left(5 \mu \mathrm{L} \cdot \mathrm{mL}^{-1}\right)$ added. Isoelectric focusing was carried out essentially as described by [16]. After focusing, the strips were equilibrated in equilibration buffer $\left(6 \mathrm{~mol} \cdot \mathrm{L}^{-1}\right.$ urea, $30 \%$ glycerol, $2 \% \mathrm{SDS}$, and $50 \mathrm{mmol} \cdot \mathrm{L}^{-1}$ Tris-HCl) with or without reducing agent ( $1 \% \mathrm{DTE})$ for $15 \mathrm{~min}$ and subsequently for another $15 \mathrm{~min}$ in nonreducing equilibration buffer, which in the case of reduced gels contained 5\% iodoacetamide. The strips were placed on the second dimension gels, and the gels were electrophoresed $(200 \mathrm{~V}, 1 \mathrm{~h})$ using running buffer as described by [16]. The gels were stained with colloidal Coomassie Brilliant Blue (CBB) G-250 (Serva, Heidelberg, Germany) [22], with the modification of [14] using aluminium sulphate (Bie \& Berntsen, Rødovre, Denmark), instead of ammonium sulphate.

\subsection{Image analysis}

The 2-DGE gels were photographed by a Vilber Lourmat digital camera (ImageHouse, Copenhagen, Denmark) equipped with Gel-Pro Analyser software. The gel spots were detected and numbered using ImageMaster 2D Platinum software (Amersham Pharmacia Biotech, Uppsala, Sweden). Gel sets 1 and 2 were subjected to comparative image analysis, and were numbered independently. Gel sets 3 and 4 were subjected to visual inspection only. After initial analysis, using automated spot detection and segmentation, all images of gels from gel sets 1 and 2 were manually checked, and the spots were matched by comparing the relative positions of the 
individual spots on each gel. The spots of the non-reducing gels were quantified by adding the pixel intensities within the spot boundary, and the spot volumes were calculated. To overcome gel-to-gel variations in spot intensities due to technical variations related to the staining procedure, the relative spot volumes were calculated for each separate spot on the gels taking into account the total staining load on each gel, and these relative values were used in the further data analysis.

\subsection{Statistical analysis}

A Student's $t$ test was carried out using Minitab 14 (Minitab Inc., State College, USA) to compare the concentrations of each milk protein in whey and rennet casein fractions obtained before and after pasteurisation using the relative spot volumes for the non-reducing gels from gel sets 1 and 2 . A two-tailed, paired $t$ test was used with a $0.95 \%$ confidence interval.

\subsection{In-gel digestion, desalting and concentration of protein spots}

Protein spots of significance were subjected to in-gel digestion by addition of trypsin essentially as described earlier [13]. Custom-made chromatographic columns were used for desalting and concentration of the peptide mixture prior to mass spectrometric analysis [17]. The peptides were eluted in $0.5 \mu \mathrm{L}$ matrix solution (15-20 $\mathrm{g} \cdot \mathrm{L}^{-1}$ of $\alpha$-cyano-4-hydroxycinnamic acid; Sigma Aldrich, St. Louis, USA, in 70\% acetonitrile) directly onto the MALDI target plate (Bruker Daltonics GmbH, Bremen, Germany).

\subsection{Identification of milk proteins by MALDI TOF mass spectrometry}

Mass spectra were obtained by peptide mass fingerprinting (PMF) using a Ultraflex MALDI-TOF tandem mass spectrometer
(Bruker Daltonics, Bremen, Germany) in reflection mode. A peptide calibration standard $(0.2 \mu \mathrm{L}$, Bruker Daltonics, Bremen, Germany) containing seven standard peptides ranging in molecular mass from 1046.54 to $3147.47 \mathrm{~g} \cdot \mathrm{mol}^{-1}$ was spotted separately onto the MALDI target plate. The ion-accelerating voltage was $25 \mathrm{kV}$ with a delay time of $40 \mathrm{~ns}$. The laser frequency was $50 \mathrm{~Hz}$, and 200 laser shots were accumulated for each spectrum. Proteins were identified by PMF by mass searches in the Swiss-Prot database (Swiss Institute of Bioinformatics, Genève, Switzerland) followed by mass searches in the database using the ion search program Mascot (Matrix Science, Boston, USA). In this program, the experimental mass value obtained from MS is compared with calculated peptide masses from a database. A scoring algorithm is used to identify the closest match. Significant protein identifications (protein scores above $62, P<0.05$ ) were reported and manually verified.

\section{RESULTS}

\subsection{Proteomic profiles of rennet casein at non-reducing and reducing conditions}

The rennet casein fractions prepared from raw or from pasteurised, skimmed milk were initially analysed by 2-DGE at the non-reducing conditions. A representative proteomic profile of the rennet casein fraction from one of the heat-treated milk samples analysed at non-reducing conditions is shown in Figure 1. It was not possible by visual examination alone, to reveal major differences in the protein profiles of the rennet casein fractions prepared from raw (result not shown) or pasteurised milk samples. The results from the comparative, statistical analysis of changes in the casein fraction as a result of pasteurisation of the skimmed milk prior to chymosin addition 


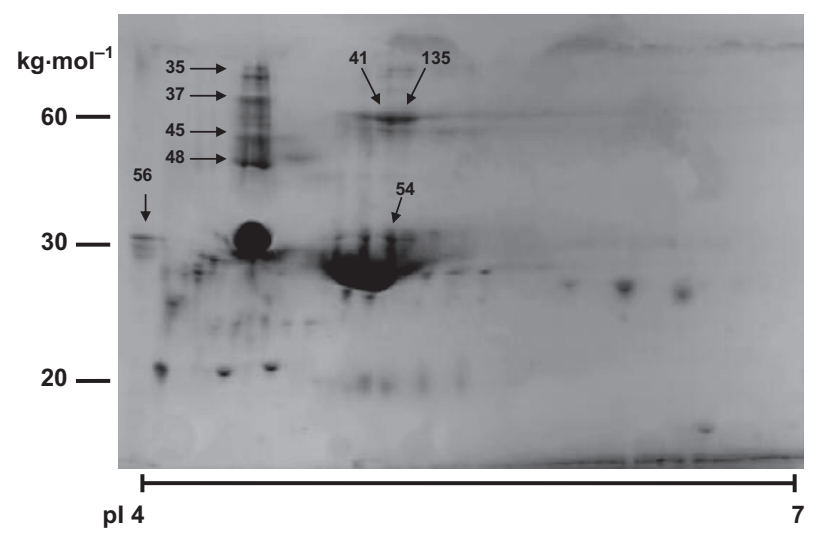

Figure 1. Non-reducing 2-DGE of rennet casein fraction from heat-treated milk visualised by colloid Coomassie Brilliant Blue G-250 staining. A representative proteomic profile of the rennet casein fraction prepared from skimmed milk of one individual cow and separated in an $8-16 \%$ polyacrylamide gel at a $\mathrm{pI}$ gradient from 4 to 7 . A total of $50 \mu \mathrm{g}$ of protein was applied. The positions of protein spots referred to in Tables I and II are indicated by an arrow and by their identification number in the image analysis of the non-reducing gels.

Table I. Means and standard deviations (SD) of relative milk protein spot volumes that differed $(P<0.050)$ or tended to differ $(P<0.100)$ in the rennet casein fractions prepared from raw $(\mathrm{R})$ or pasteurised (P) milk. See Table II for details of the MS identifications.

\begin{tabular}{llccccccc}
\hline Spot ID & Protein & Mean R & SD & Mean P & SD & $n$ & $\mathrm{R} \rightarrow \mathrm{P}^{1}$ & $P$ value \\
\hline 35 & $\alpha_{\mathrm{S} 1}-\mathrm{CN}$ & 0.444 & 0.174 & 0.709 & 0.252 & 5 & $\uparrow$ & 0.034 \\
37 & $\alpha_{\mathrm{S} 1}-\mathrm{CN}$ & 0.685 & 0.183 & 1.109 & 0.240 & 5 & $\uparrow$ & 0.035 \\
45 & $\alpha_{\mathrm{S} 1}-\mathrm{CN}$ & 0.873 & 0.281 & 1.983 & 0.600 & 5 & $\uparrow$ & 0.082 \\
48 & $\alpha_{\mathrm{S} 1}-\mathrm{CN}$ & 0.746 & 0.469 & 1.279 & 0.283 & 5 & $\uparrow$ & 0.085 \\
54 & $\alpha_{\mathrm{S} 2}-\mathrm{CN}$ & 1.615 & 0.673 & 2.216 & 0.806 & 5 & $\uparrow$ & 0.027 \\
\hline
\end{tabular}

${ }^{1}$ Direction of change of relative spot volume in samples in relation to pasteurisation.

are shown in Table I. Five protein spots differed $(P<0.05)$ or tended to differ $(P<0.1)$ between rennet casein fractions prepared from raw or from pasteurised milk, and they were all found to increase after pasteurisation (Tab. I). These spots are indicated in Figure 1, and they include a series of less well-defined proteins arranged in a vertical row in the higher molecular mass region (spots with IDs 35, 37, 45 and 48 in Fig. 1) above the position of the majority of caseins. Furthermore, the intensity of spot ID 54 was significantly higher in the rennet casein fraction prepared from pasteurised milk compared to that from raw milk (Tab. I). When comparing the rennet casein fraction in milk from one individual cow at non-reducing conditions (Fig. 1) with the same sample analysed at reducing conditions (Fig. 2), it was seen that the spots with IDs $35,37,45$ and 48 (numbering according to gel in Fig. 1) were present at both nonreducing and reducing conditions. This implies that these complexes were not connected by disulphide bonds. Further comparison of the rennet casein fractions 


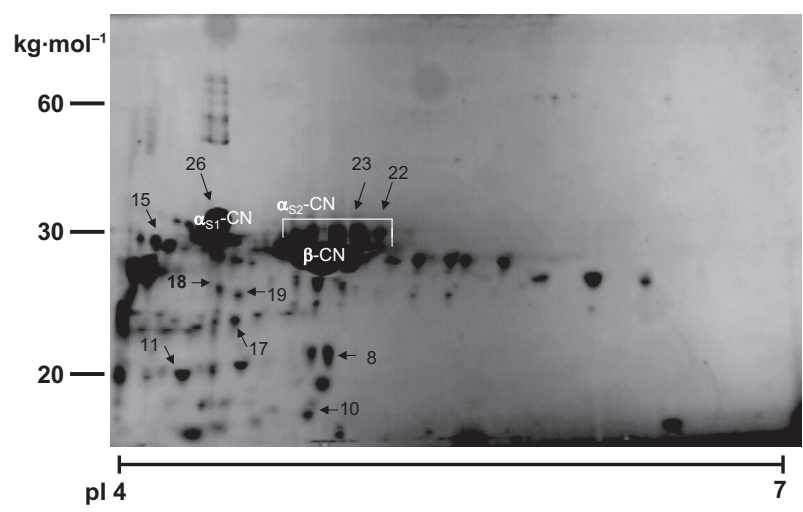

Figure 2. Reducing 2-DGE of rennet casein fraction from heat-treated milk visualised by colloid Coomassie Brilliant Blue G-250 staining. The conditions of the 2-DGE were as described in Figure 1 legend, except that this gel was run at reducing conditions as described in Materials and Methods. The sample analysed in Figures 1 and 2 was from the same individual cow. The positions of protein spots referred to in Tables I and II are indicated by an arrow and by their identification number in the image analysis of the reduced gels. The positions of major caseins assigned according to [31] are indicated in white.

analysed at non-reducing and reducing conditions, respectively, revealed as expected that the positions of most major spots were comparable. One major difference was the presence of spot IDs 41 and 135 in Figure 1 at non-reducing conditions, while they were absent at reducing conditions (Fig. 2). Generally, the spots obtained at reducing conditions were well-defined and more easily detected.

\subsection{MS identifications of protein spots in the rennet casein fraction}

Proteins in the rennet casein fraction were excised from both gel types (Figs. 1 and 2) and identified by PMF using MALDI TOF MS analyses or by comparison with earlier published proteomic patterns of proteins in chymosin-separated whey and casein fractions [32]. The results from the MS analyses are presented in Table II. In the non-reducing gel, no protein other than $\alpha_{\mathrm{S} 1}-\mathrm{CN}$ was identified to be present in the spots with IDs 35, 37, 45 and 48, which were the spots either being significantly different or tending to differ between rennet casein from raw or pasteurised milk (Fig. 1 and Tab. II). Furthermore, the spot with ID 56 in Figure 1 was also found to represent $\alpha_{\mathrm{S} 1}-\mathrm{CN}$. As expected, one of the major differences between the rennet casein fraction analysed at reducing or non-reducing conditions was the presence of the disulphide-bonded $\alpha_{\mathrm{S} 2}-\mathrm{CN}$ dimer in the 2-DGE gel in Figure 1, identified at the positions of spot IDs 41 and 135 (Tab. II). Two of the $\alpha_{\mathrm{S} 2}-\mathrm{CN}$ monomer isoforms were identified by MS (Tab. II and Fig. 2, spot IDs 22 and 23). By comparison of these identifications with the position of spot ID 54 in Figure 1, which was found to increase significantly in intensity after pasteurisation, it is evident that spot ID 54 represents an $\alpha_{\mathrm{S} 2}-\mathrm{CN}$ monomer isoform.

Further identifications in the reduced gel included the position of the major $\alpha_{\mathrm{S}_{1}-\mathrm{CN}}$ spot with ID 26 in Figure 2, in addition to some minor spots with lower molecular 
Table II. Proteins in the rennet casein fraction (Figs. 1 and 2) identified by MALDI-TOF MS after non-reducing $(-)$ or reducing $(+)$ 2-DGE.

\begin{tabular}{|c|c|c|c|c|c|c|c|}
\hline $\begin{array}{l}\text { Spot } \\
\text { ID }\end{array}$ & Protein & $\begin{array}{l}\text { Sequence } \\
\text { coverage }^{\mathrm{a}}\end{array}$ & $\begin{array}{l}\text { Matched } \\
\text { peptides }^{\mathrm{b}}\end{array}$ & Score $^{c}$ & $\begin{array}{c}\text { Theoretical } \\
\mathrm{pI}^{\mathrm{d}}\end{array}$ & $\begin{array}{c}\text { Theoretical } \\
\mathrm{Mw}^{\mathrm{e}}\end{array}$ & $\begin{array}{c}\text { Access } \\
\text { key }^{\mathrm{f}}\end{array}$ \\
\hline \multicolumn{8}{|c|}{ Rennet casein $(-)$} \\
\hline 35 & $\alpha_{\mathrm{S} 1}$-casein & 19 & 4 & $61^{*}$ & 4.89 & 24.6 & P02662 \\
\hline 37 & $\alpha_{\mathrm{S} 1}$-casein & 22 & 4 & 51 & 4.89 & 24.6 & P02662 \\
\hline 41 & $\alpha_{\mathrm{S} 2}$-casein & 28 & 10 & $85^{*}$ & 4.60 & 26.0 & P02663 \\
\hline 45 & $\alpha_{\mathrm{S} 1 \text {-casein }}$ & 19 & 4 & $68^{*}$ & 4.89 & 24.6 & P02662 \\
\hline 48 & $\alpha_{\mathrm{S} 1}$-casein & 19 & 4 & 56 & 4.89 & 24.6 & P02662 \\
\hline 56 & $\alpha_{\mathrm{S} 1}$-casein & 19 & 4 & 56 & 4.89 & 24.6 & P02662 \\
\hline 81 & $\beta$-lactoglobulin & 30 & 6 & $65^{*}$ & 4.93 & 20.3 & P02754 \\
\hline 135 & $\alpha_{\mathrm{S} 2}$-casein & 25 & 7 & $74^{*}$ & 4.60 & 26.0 & P02663 \\
\hline \multicolumn{8}{|c|}{ Rennet casein $(+)$} \\
\hline 8 & $\beta$-lactoglobulin & 37 & 9 & $106^{*}$ & 4.93 & 20.3 & P02754 \\
\hline 10 & $\alpha$-lactalbumin & 23 & 6 & $65^{*}$ & 4.93 & 17.0 & P00711 \\
\hline 11 & $\alpha_{\mathrm{S} 1}$-casein & 22 & 4 & 51 & 4.89 & 24.6 & P02662 \\
\hline 15 & $\alpha_{\mathrm{S} 1 \text {-casein }}$ & 23 & 4 & 49 & 4.89 & 24.6 & P02662 \\
\hline 17 & $\alpha_{\mathrm{S} 1}$-casein & 22 & 4 & 51 & 4.89 & 24.6 & P02662 \\
\hline 18 & $\alpha_{\mathrm{S} 1}$-casein & 30 & 6 & $69^{*}$ & 4.89 & 24.6 & P02662 \\
\hline 19 & $\alpha_{\mathrm{S} 1}$-casein & 22 & 4 & 53 & 4.89 & 24.6 & P02662 \\
\hline 22 & $\alpha_{\mathrm{S} 2}$-casein & 29 & 8 & $108^{*}$ & 4.60 & 26.0 & P02663 \\
\hline 23 & $\alpha_{\mathrm{S} 2}$-casein & 18 & 6 & 56 & 4.60 & 26.0 & P02663 \\
\hline 26 & $\alpha_{\mathrm{S} 1}$-casein & 22 & 4 & 44 & 4.89 & 24.6 & P02662 \\
\hline
\end{tabular}

${ }^{a}$ The minimum coverage of the matched peptides in relation to the full-length sequence.

${ }^{\mathrm{b}}$ The number of matched peptides in the database search.

${ }^{c}$ Score of the Mascot search. Significant scores $(P<0.05)$ are marked by *.

d Theoretical pI of the full-length protein.

e Theoretical molecular mass (Mw) of the full-length protein in $\mathrm{kg} \cdot \mathrm{mol}^{-1}$.

${ }^{\mathrm{f}}$ Primary accession key in the SWISS-PROT database.

masses, all containing $\alpha_{\mathrm{S} 1}-\mathrm{CN}$ (spot IDs 11 , 15, 17, 18 and 19, Fig. 2). Small amounts of the whey proteins $\alpha$-LA (spot ID 10) and $\beta$-LG (spot ID 8) were also identified.

\subsection{Proteomic profiles of proteins in sweet whey at non-reducing and reducing conditions}

The protein profile of one of the sweet whey samples analysed at non-reducing conditions is shown in Figure 3. As observed for the rennet casein fraction, it was not possible by visual examination only to reveal major differences in the protein profiles of sweet whey prepared from raw (result not shown) or from pasteurised, skimmed milk (Fig. 3). The results from the comparative analysis of the protein profiles of sweet whey prepared from skimmed milk before and after pasteurisation are presented in Table III. A total of 13 protein spots was either different or tended to be different when comparing sweet whey from raw or pasteurised milk. Of these, six spots (with IDs 48, 49, 50, 51, 53 and 57) were found to decrease in intensity after pasteurisation, whereas seven spots (with IDs 92, 93, 94, 95, 97, 160 and 186) increased in intensity after pasteurisation (Tab. III). The positions of these spots, which differed $(P<0.05)$ or tended to differ $(P<0.1)$ in sweet whey prepared before and after 


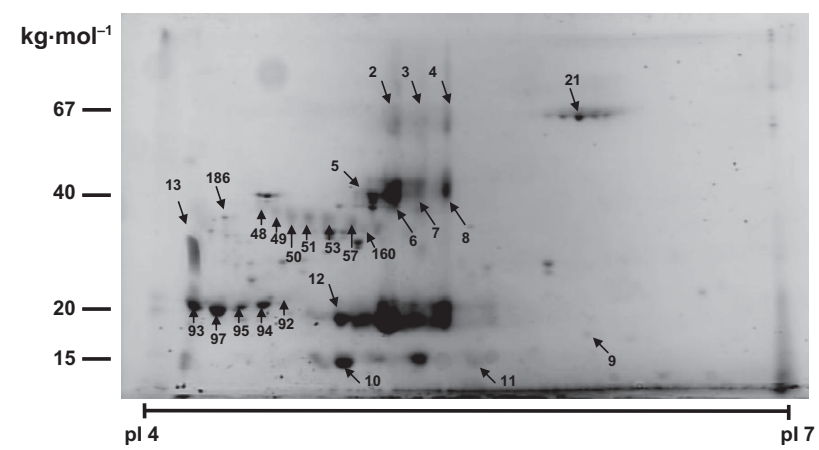

Figure 3. Non-reducing 2-DGE of sweet whey fraction from heat-treated milk visualised by colloid Coomassie Brilliant Blue G-250 staining. The sweet whey was prepared from skimmed milk of one representative individual cow and separated in an $8-16 \%$ polyacrylamide gel at a $\mathrm{pI}$ gradient from 4 to 7 . A total of $150 \mu \mathrm{g}$ of protein was applied. The positions of protein spots referred to in Tables III and IV are indicated by an arrow and by their identification number in the image analysis of the non-reducing gels.

Table III. Means and standard deviations (SD) of relative milk protein spot volumes that differed $(P<0.050)$ or tended to differ $(P<0.100)$ in the sweet whey fractions prepared from raw $(\mathrm{R})$ or pasteurised $(\mathrm{P})$ milk.

\begin{tabular}{llccccccc}
\hline Spot ID & Protein & Mean R & SD & Mean P & SD & $n$ & $\mathrm{R} \rightarrow \mathrm{P}^{1}$ & $P$ value \\
\hline 48 & Lactophorin/PP3 & 0.941 & 0.172 & $0.672^{1}$ & 0.217 & 6 & $\downarrow$ & 0.058 \\
49 & Lactophorin/PP3 & 1.532 & 0.194 & 0.999 & 0.314 & 6 & $\downarrow$ & 0.012 \\
50 & Lactophorin/PP3 & 2.539 & 0.393 & 1.860 & 0.517 & 6 & $\downarrow$ & 0.019 \\
51 & Lactophorin/PP3 & 3.391 & 0.591 & 2.663 & 0.600 & 6 & $\downarrow$ & 0.028 \\
53 & Lactophorin/PP3 & 3.344 & 0.685 & 2.217 & 0.706 & 6 & $\downarrow$ & 0.015 \\
57 & Lactophorin/PP3 & 2.188 & 0.519 & 1.741 & 0.523 & 6 & $\downarrow$ & 0.005 \\
92 & $\alpha_{\mathrm{S} 1}-\mathrm{CN}$ & 0.961 & 0.572 & 1.972 & 1.054 & 6 & $\uparrow$ & 0.040 \\
93 & $\alpha_{\mathrm{S} 1}-\mathrm{CN}$ & 3.400 & 1.780 & 4.480 & 2.560 & 6 & $\uparrow$ & 0.035 \\
94 & $\alpha_{\mathrm{S} 1}-\mathrm{CN}$ & 1.323 & 0.733 & 2.926 & 1.730 & 6 & $\uparrow$ & 0.058 \\
95 & $\alpha_{\mathrm{S} 1}-\mathrm{CN}$ & 2.733 & 1.619 & 5.136 & 2.250 & 6 & $\uparrow$ & 0.001 \\
97 & $\alpha_{\mathrm{S} 1}-\mathrm{CN}$ & 2.260 & 2.570 & 3.580 & 3.090 & 6 & $\uparrow$ & 0.021 \\
160 & Not known & 0.049 & 0.120 & 0.262 & 0.299 & 6 & $\uparrow$ & 0.058 \\
186 & Not known & 0.093 & 0.105 & 0.342 & 0.260 & 6 & $\uparrow$ & 0.012 \\
\hline
\end{tabular}

${ }^{1}$ Direction of change of relative spot volume in samples in relation to pasteurisation.

pasteurisation, are indicated in Figure 3. The spots with IDs 48, 49, 50, 51, 53 and 57 were found to represent a chain of related spots with differences in $\mathrm{pI}$ and with slightly decreasing apparent mass with increasing pI. The spots with IDs 92, 93, 94, 95 and 97 also represented a chain of related spots, which differed in $\mathrm{pI}$, but not in molecular mass. For comparison the 2-DGE proteomic profile of the proteins in the sweet whey prepared from heat-treated, skimmed milk at reducing conditions is shown in Figure 4. The positions of the major whey proteins are indicated. It is seen that the separation 


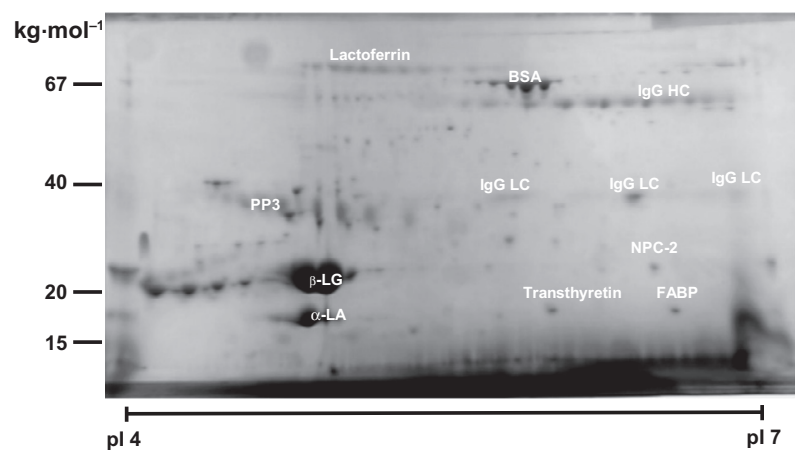

Figure 4. Reducing 2-DGE of sweet whey fraction from heat-treated milk visualised by colloid Coomassie Brilliant Blue G-250 staining. The conditions of the 2-DGE were as described in Figure 1 legend, except that this gel was run at reducing conditions as described in Materials and Methods. The positions of protein spots referred to in Table IV are indicated by an arrow and by their identification number in the image analysis of the reduced gels. The positions of major whey proteins assigned according to [31] are indicated in white. FABP, fatty acid binding protein; IgG HC, immunoglobulin G heavy chain; IgG LC, immunoglobulin G light chain; NPC2, Niemann Pick type 2 protein/EPV20; BSA, bovine serum albumin; and PP3, proteose peptone component 3.

and detection are improved at reducing conditions, as a range of additional spots are present in the reduced gel. This also indicates their presence in disulphide-linked molecular structures, which can be either "native", like e.g. immunoglobulin $\mathrm{G}$, or induced by the heat treatment. Furthermore, the spots with IDs 2, 3, 4, 5, 6, 7 and 8 (numbering according to gel in Fig. 3) were not present in the reduced gel, while the remaining spots indicated by arrows and IDs in Figure 3 were also present in the reduced gel in Figure 4, which shows that they are not linked by disulphides.

\subsection{MS identifications of protein spots in the sweet whey fractions}

Protein spots in the sweet whey fraction as identified by PMF and MALDI TOF MS are presented in Table IV. Some of these spots were found by the $t$ test to differ significantly or tended to differ in response to pasteurisation (Tab. III), whereas others corresponded to prominent spots in the sweet whey 2-DGE gel (Fig. 3). The spots with decreased intensity after pasteurisation were identified as PP3 or lactophorin (spot IDs 48, 49, 50, 51 and 57, Tab. IV). Even though the spot with ID 160 was located close to PP3, it was located in between the detected PP3 spots, and in contrast to PP3, it furthermore increased at pasteurisation and could not be identified by MS. In the other range of spots, whose intensity increased after pasteurisation, one spot was identified to contain $\alpha_{\mathrm{S} 1}-\mathrm{CN}$ (spot ID 93). The molecular mass of this spot is considerably lower than the mass of intact $\alpha_{\mathrm{S} 1}-\mathrm{CN}$, and therefore the spots in this region represent fragments of $\alpha_{\mathrm{S} 1}-\mathrm{CN}$, most likely induced by chymosin hydrolysis. Further identifications of proteins present in the sweet whey at non-reducing conditions included $\beta$-LG, which was present in several molecular mass zones, probably corresponding to monomer (spot ID 12), dimer (spot IDs 5, 6, 7 and 8) and probably trimer states of $\beta$-LG (spot IDs 2, 3 and 4), which also contained $\beta$-LG, had an apparent mass just below that of BSA (spot ID 21). Furthermore, another spot from sweet whey representing $\alpha_{\mathrm{S} 1}-\mathrm{CN}$ (spot ID 13) 
Table IV. Proteins in sweet whey fraction (Fig. 3) identified by MALDI TOF MS after nonreducing (-) 2-DGE.

\begin{tabular}{|c|c|c|c|c|c|c|c|}
\hline Spot ID & Protein & $\begin{array}{l}\text { Sequence } \\
\text { coverage }^{\mathrm{a}}\end{array}$ & $\begin{array}{l}\text { Matched } \\
\text { peptides }^{b}\end{array}$ & Score $^{c}$ & $\begin{array}{c}\text { Theoretical } \\
\mathrm{pl}^{\mathrm{d}}\end{array}$ & $\begin{array}{c}\text { Theoretical } \\
\mathrm{Mw}^{\mathrm{e}}\end{array}$ & $\begin{array}{c}\text { Access } \\
\text { key }^{\text {f }}\end{array}$ \\
\hline \multicolumn{8}{|c|}{ Sweet whey $(-)$} \\
\hline 2 & $\beta$-lactoglobulin & 11 & 2 & 32 & 4.93 & 20.3 & P02754 \\
\hline 3 & $\beta$-lactoglobulin & 29 & 6 & $75^{*}$ & 4.93 & 20.3 & P02754 \\
\hline 4 & $\beta$-lactoglobulin & 29 & 6 & $75^{*}$ & 4.93 & 20.3 & P02754 \\
\hline 5 & $\beta$-lactoglobulin & 17 & 4 & 49 & 4.93 & 20.3 & P02754 \\
\hline 6 & $\beta$-lactoglobulin & 11 & 3 & 31 & 4.93 & 20.3 & P02754 \\
\hline 7 & $\beta$-lactoglobulin & 19 & 5 & $62 *$ & 4.93 & 20.3 & P02754 \\
\hline 8 & $\beta$-lactoglobulin & 17 & 4 & 56 & 4.93 & 20.3 & P02754 \\
\hline 9 & FABP $^{\circ}$ & 37 & 5 & $79 *$ & 6.14 & 14.7 & P10790 \\
\hline 10 & $\alpha$-lactalbumin & 28 & 6 & $116^{*}$ & 4.93 & 16.69 & P00711 \\
\hline 11 & $\alpha$-lactalbumin & 22 & 3 & 48 & 4.93 & 16.69 & P00711 \\
\hline 12 & $\beta$-lactoglobulin & 11 & 3 & 34 & 4.93 & 20.3 & P02754 \\
\hline 13 & $\alpha_{\mathrm{S} 1 \text {-casein }}$ & 23 & 3 & 46 & 4.89 & 24.6 & P02662 \\
\hline 21 & $\mathrm{BSA}^{\mathrm{g}}$ & 16 & 8 & $78^{*}$ & 5.80 & 71.2 & P02769 \\
\hline 48 & Lactophorin/PP3 & 16 & 4 & 52 & 6.2 & 17.2 & P80195 \\
\hline 49 & Lactophorin/PP3 & 25 & 6 & $68^{*}$ & 6.2 & 17.2 & P80195 \\
\hline 50 & Lactophorin/PP3 & 22 & 4 & 49 & 6.2 & 17.2 & P80195 \\
\hline 51 & Lactophorin/PP3 & 39 & 6 & $81 *$ & 6.2 & 17.2 & P80195 \\
\hline 57 & Lactophorin/PP3 & 16 & 4 & 52 & 6.2 & 17.2 & P80195 \\
\hline 93 & $\alpha_{\mathrm{S} 1}-\mathrm{CN}$ & 23 & 4 & 58 & 4.89 & 24.6 & P02662 \\
\hline
\end{tabular}

a The minimum coverage of the matched peptides in relation to the full-length sequence.

b The number of matched peptides in the database search.

${ }^{\mathrm{c}}$ Score of the Mascot search. Significant scores $(P<0.05)$ are marked by $*$.

d Theoretical pI of the full-length protein.

e Theoretical molecular mass (Mw) of the full-length protein in $\mathrm{kg} \cdot \mathrm{mol}^{-1}$.

${ }^{\mathrm{f}}$ Primary accession key in the SWISS-PROT database.

${ }^{g}$ FABP and BSA correspond to fatty acid binding protein and bovine serum albumin, respectively.

was identified, in addition to $\alpha$-LA (spot IDs 10 and 11), bovine serum albumin (BSA) and fatty acid binding protein (FABP) (Tab. IV). MS did not identify the protein representing the spot with ID 186, of which a small amount was present.

\section{DISCUSSION}

Proteome analysis using 2-DGE was used to investigate the protein profiles of sweet whey and rennet casein fractions prepared from pasteurised, skimmed milk. The sweet whey and rennet casein fractions prepared by addition of chymosin to skimmed milk were analysed separately by 2-DGE. As some of the potential changes in the milk protein fraction in response to heat treatment may involve changes in disulphide bridges, both non-reducing and reducing conditions for the 2-DGE analyses were applied. In relation to traditional 2-DGE analyses, non-reducing conditions involved omission of the reducing agent from the respective buffers used in the procedure, and in this study this was omitted from the buffers used in both dimensions. In a separate study of the changes induced by LTST treatment, it would be possible, to evaluate the effect of omission of reducing agents in each of the dimensions separately. 
This approach was recently used in a study of heat-induced changes at more severe conditions $\left(90{ }^{\circ} \mathrm{C}\right.$ for up to $30 \mathrm{~min}$ ) and showed the presence of various complexes containing not only the disulphide-containing proteins such as $\kappa-\mathrm{CN}, \alpha_{\mathrm{S} 2}-\mathrm{CN}$ and BSA, but also $\beta$ - and $\alpha_{\mathrm{S} 1}-\mathrm{CN}$, containing no disulphides [3].

The $\alpha_{\mathrm{S} 2}-\mathrm{CN}$ dimer was seen at the nonreducing conditions, where the disulphide bonds between the two monomers are intact [26]. Due to the addition of chymosin, the $\kappa-\mathrm{CN}$ was cleaved into para- $\kappa-\mathrm{CN}$ and CMP. However, neither of these cleavage products was identified. CMP was not detected in the gels, probably due to its low pI. The theoretical pI of CMP is 4.04 and therefore focuses very close to the limit of the pI strip used ( $\mathrm{pH} 4-7)$. Glycosylation of the CMP would be expected to lower the $\mathrm{pI}$ of CPM even more, through the introduction of sialic acids. The mass of CMP is approximately $8000-10000 \mathrm{~g} \cdot \mathrm{mol}^{-1}$, depending on the extent of glycosylation, and therefore just exactly retained in the gels. Due to the loss of the glycosylations and phosphorylations residing in the CMP fragment, para- $\kappa-\mathrm{CN}$ is homogeneous with a theoretical $\mathrm{pI}$ of 9.33 and therefore focuses outside the $\mathrm{pH}$ of the strip. Chymosin is known to cleave $\alpha_{\mathrm{S} 1}-\mathrm{CN}$ at several sites, resulting in the generation of both larger fragments, such as $\alpha_{\mathrm{S} 1}-\mathrm{I} \mathrm{CN}$, and in some smaller peptides with sizes down to a few amino acid residues, as observed in an HPLC study [21]. Of the latter, probably only polypeptides with masses above 7000-10 $000 \mathrm{~g} \cdot \mathrm{mol}^{-1}$ and a $\mathrm{pI}$ in the range applied can be seen on the 2-DGE gels. A considerable number of fragments with altered $\mathrm{pI}$ or molecular mass in relation to intact $\alpha_{\mathrm{S} 1}-\mathrm{CN}$ appeared below the position of $\alpha_{\mathrm{S} 1}-\mathrm{CN}$, and they are suggested to represent fragments of $\alpha_{\mathrm{S} 1}-\mathrm{CN}$ created as a result of chymosin activity. In the present study of rennet casein, five of these were actually shown by MS to contain $\alpha_{\mathrm{S} 1}-\mathrm{CN}$ (spots with IDs $11,15,17,18$ and 19 in Fig. 2). The spot with ID 15 may represent $\alpha_{\mathrm{S} 1}-\mathrm{I} \mathrm{CN}$ (i.e. f24-199), corresponding to the loss of molecular mass of a few thousands of $\mathrm{g} \cdot \mathrm{mol}^{-1}$ and a more negative $\mathrm{pI}$ due to the net positive charge of the fragment being cleaved off (f1-23 of $\alpha_{\mathrm{S} 1}-\mathrm{CN}$ ) compared with an intact $\alpha_{\mathrm{S} 1}-\mathrm{CN}$. A precise identification of the $\alpha_{\mathrm{S} 1}-\mathrm{CN}$ fragments present in these spots would require additional MS using a top-down approach and/or MS/MS analyses of individual peptides. The resolution of the appreciable number of $\alpha_{\mathrm{S} 1}-\mathrm{CN}$ fragments demonstrates, however, that 2-DGE is a powerful method for the separation of the larger fragments of $\alpha_{\mathrm{S} 1}-\mathrm{CN}$ generated as a result of cleavage by chymosin. The 2-DGE method thus supplements application of urea PAGE and HPLC methods often used for separation of casein fragments, and could, in combination with MS methods, be used to monitor, e.g. the initial proteolysis during cheese ripening.

The spots in the rennet casein and sweet whey fractions prepared from the six individual cow's milk samples before and after pasteurisation, as analysed at non-reducing 2-DGE conditions, were subjected to semiquantitative analyses using their relative spot values. In the present study, Coomassie blue staining was used, as this staining has a larger dynamic range than silver staining, which otherwise has been used in many proteomic studies. The Coomassie blue staining is less sensitive than silver staining, and this is an advantage for quantitative analysis of major proteins, such as caseins, while silver staining is more suitable for monitoring minor proteins in milk [32]. Overall, the 2-D gel pictures of the rennet casein samples prepared from either the raw or pasteurised milk had the same appearance.

By the statistical $t$ test analysis, five protein spots in the rennet casein fraction were found to increase or tended to increase after pasteurisation. Among these, four spots were identified to contain $\alpha_{\mathrm{S} 1}-\mathrm{CN}$, whereas one corresponded to $\alpha_{\mathrm{S} 2}-\mathrm{CN}$. The molecular 
masses of the four $\alpha_{\mathrm{S} 1}-\mathrm{CN}$-containing spots, which were positively associated with heat treatment, were considerably higher than the expected mass of native $\alpha_{\mathrm{S1}}-\mathrm{CN}$, and therefore they are suggested to represent some kind of modified $\alpha_{\mathrm{S}_{1}}-\mathrm{CN}$. As $\alpha_{\mathrm{S1}^{-}}$ $\mathrm{CN}$ does not contain cysteine residues, the higher molecular mass complexes containing $\alpha_{\mathrm{S} 1}-\mathrm{CN}$ are not due to introduction of disulphide bridges. The nature of these complexes is not known. One possibility is that the formation of higher molecular mass forms of $\alpha_{\mathrm{S} 1}-\mathrm{CN}$ could be the result of protein oxidation occurring during heat treatment of the samples and leading to multimer formation, e.g. via the introduction of dityrosines. Alpha ${ }_{\mathrm{S} 1}-\mathrm{CN}$ and $\alpha_{\mathrm{S} 2}-\mathrm{CN}$ were recently shown to be relatively amenable to the introduction of dityrosine after protein oxidation in model studies, and both the formation of dimers and of higher polymers of $\alpha_{\mathrm{S} 1}-\mathrm{CN}$ were observed [4]. The polymerisation could be due to associations between intact $\alpha_{\mathrm{S} 1}-\mathrm{CN}$ molecules, but also to associations between intact $\alpha_{\mathrm{S}_{1}-\mathrm{CN}}$ and chymosin-generated fragments thereof, or between fragments alone. The demonstration of this would, however, require further studies, e.g. by MS/MS analysis. This is difficult, as only small fraction of the tyrosines in the molecules is expected to be modified. The reason why one spot containing $\alpha_{\mathrm{S} 2}-\mathrm{CN}$ monomer isoform (ID 54, Fig. 1) was elevated after pasteurisation could not be explained.

In the present study, no changes were detected in spots containing complexes of $\beta-\mathrm{LG}$ and $\kappa-\mathrm{CN}$, which is known to occur at heat treatment of skimmed milk, especially at $\mathrm{pH}$ values above 6.7 [11]. These complexes can be present both in association with casein and in the milk serum phase [6], but in the present study they were neither observed in the casein nor in the whey fraction studies. This may be explained by several factors. In the present study, the $\mathrm{pH}$ of the milk used was 6.7. Furthermore, the added chymosin may have hydrolysed the $\kappa-\mathrm{CN}$ in eventual complexes formed at the gentle heat treatment $\left(72{ }^{\circ} \mathrm{C}\right.$ for $\left.15 \mathrm{~s}\right)$ applied in this study. This is in accordance with earlier findings, where pronounced whey protein denaturation was observed only at more severe heat treatments [12]. It has been reported that the concentration of denatured whey proteins was only $2.8 \%$ in milk pasteurised at $72{ }^{\circ} \mathrm{C}$ for $26 \mathrm{~s}$, whereas the concentration increased to $8.4 \%$ when increasing the temperature to $87^{\circ} \mathrm{C}$ [27]. Using the more severe heat treatment of $85^{\circ} \mathrm{C}$ for $30 \mathrm{~min}$ resulted in a marked decrease in the concentration and number of proteins in whey as compared to a heat treatment of $65^{\circ} \mathrm{C}$ for $30 \mathrm{~min}$ [18].

In the sweet whey fraction, protein spots were found to both increase and decrease after pasteurisation. The range of protein spots, which was found to decrease in sweet whey after pasteurisation, was identified as PP3. PP3, or lactophorin, a component from the proteose peptone fraction of milk, contains both multiple sites of phosphorylation and of glycosylation $[15,28]$, which is the reason for its presence at different $\mathrm{pI}$ and mass ranges by the 2-DGE analysis. The finding that PP3 decreased in sweet whey after pasteurisation is surprising, as the protein is considered to be relatively heat stable [9]. It is possible, however, that heat treatment changes the distribution of PP3 among different milk fractions, e.g. increasing its association with the milk fat globule membrane. Another explanation could be that the multimeric nature of PP3 is positively affected in favour of the monomeric structure by pasteurisation [2, 29], and so it is probably not adsorbed into the strip during the 1st dimension 2-DGE procedure.

In the whey fraction, protein spots found to increase in response to pasteurisation included a range of spots of which one was identified by MS to contain $\alpha_{\mathrm{S} 1}-\mathrm{CN}$ (spot ID 93, Tab. IV). Due to the mass difference from intact $\alpha_{\mathrm{S}_{1}}-\mathrm{I} \mathrm{CN}$, these spots probably represent further cleavage products 
of $\alpha_{\mathrm{S} 1}$-I $\mathrm{CN}$ by chymosin, e.g. at position $\operatorname{Trp}_{164}-\mathrm{Phe}_{165}$ peptide bond [21], yielding f24-164. This fragment would comprise 142 residues corresponding to a molecular mass of approximately $17000 \mathrm{~g} \cdot \mathrm{mol}^{-1}$, i.e. close to the mass of $\beta-\mathrm{LG}$, as observed in Figure 3. The occurrence of this proposed fragment at various $\mathrm{pI}$ values could be due to variations in phosphorylations. One possible explanation for the increase of this fragment in the whey fraction after pasteurisation could be that $\alpha_{\mathrm{S} 1}$-I CN becomes more available as a substrate for chymosin hydrolysis after pasteurisation, which may be due to decreased stability of the molecule at temperatures above $70{ }^{\circ} \mathrm{C}$ [19]. However, this was not studied further. Future studies could include the use of quantitative proteomics, like iTRAQ methodology [8], of other types of heat-treated milk, as well as additional studies using MS and/or MS/MS analysis for identification of casein fragments induced by chymosin hydrolysis as detected in the 2-DGE gels.

\section{CONCLUSIONS}

The main findings of this work include the finding of increased spot volumes of molecules containing high-molecular forms of $\alpha_{\mathrm{S} 1}-\mathrm{CN}$ in the rennet casein fraction prepared from heat-treated, skimmed milk. Because $\alpha_{\mathrm{S} 1}-\mathrm{CN}$ does not contain cysteine residues, and therefore no disulphide bridges, it does not participate in larger complexes based on disulphides. Instead, the increase in the high-molecular mass forms of $\alpha_{\mathrm{S}_{1}}-\mathrm{CN}$ is suggested to be due to some kind of polymerisation of intact $\alpha_{\mathrm{S} 1}-\mathrm{CN}$ molecules and/or $\alpha_{\mathrm{S} 1}-\mathrm{CN}$ fragments. In the sweet whey fraction, a range of protein spots was found to either decrease or increase in intensity after pasteurisation. The content of PP3/lactophorin was decreased in whey prepared from pasteurised, skimmed milk compared to whey prepared from raw milk, whereas one of the increasing spots after pasteurisation contained an $\alpha_{\mathrm{S} 1}-\mathrm{CN}$ fragment, perhaps due to increased susceptibility of $\alpha_{\mathrm{S} 1}-\mathrm{CN}$ to chymosin after heat treatment. However, the changes that occurred in the milk protein profile as a result of pasteurisation and as analysed by non-reducing 2-DGE were relatively small.

Acknowledgements: The authors wish to thank Hanne Søndergaard Møller, Stina Greis Handberg, Rita Albrechtsen and Helle Louise Christensen, Department of Food Science, Faculty of Agricultural Sciences, Aarhus University, for excellent technical assistance. The Danish Research Foundation, the Innovation law and the Swedish Farmer's Foundation for Agricultural Research are gratefully acknowledged for their financial support.

Part of this work was presented at the $5^{\text {th }}$ IDF symposium on cheese ripening, 9-13 March 2008, Bern, Switzerland, as poster and abstract.

\section{REFERENCES}

[1] Allmere T., Andren A., Lindersson M., Björck L., Studies on rheological properties of stirred milk gels made from milk with defined genetic variants of $\kappa$-casein and $\beta$-lactoglobulin, Int. Dairy J. 8 (1998) 899905.

[2] Campagna S., Cosette P., Molle G., Gaillard J.L., Evidence for membrane affinity of the C-terminal domain of bovine milk PP3 component, Biochim. Biophys. Acta, Biomembranes 1513 (2001) 217-222.

[3] Chevalier F., Hirtz C., Sommerer N., Kelly A.L., Use of reducing/nonreducing twodimensional electrophoresis for the study of disulfide-mediated interactions between proteins in raw and heated bovine milk, J. Agric. Food Chem. 57 (2009) 5948-5955.

[4] Dalsgaard T.K., Otzen D., Nielsen J.H., Larsen L.B., Changes in structures of milk proteins upon photo-oxidation, J. Agric. Food Chem. 55 (2007) 10968-10976.

[5] de Wit J.N., Klarenbeek G., Hontelez-Backx E., Evaluation of functional properties of whey protein concentrates and whey protein isolates. Isolation and characterization, Neth. Milk Dairy J. 37 (1983) 37-49. 
[6] Donato L., Guyomarc'h F., Formation and properties of the whey protein/ $/$-casein complexes in heated skim milk - A review, Dairy Sci. Technol. 89 (2009) 3-29.

[7] Fong B.F., Norris C.S., Palmano K.P., Fractionation of bovine whey proteins and characterisation by proteomic techniques, Int. Dairy J. 18 (2008) 23-46.

[8] Gagnaire V., Jardin J., Jan G., Lortal S., Proteomics of milk and bacteria used in fermented dairy products: from qualitative to quantitative advances, J. Dairy Sci. 92 (2009) 811-825.

[9] Girardet J.-M., Linden G., PP3 component of bovine milk: a phosphorylated whey glycoprotein, J. Dairy Res. 63 (1996) 333-350.

[10] Guillou H., Miranda G., Pelissier J.-P., Hydrolysis of $\beta$-casein by gastric proteases, Int. J. Pept. Protein Res. 37 (1991) 494-501.

[11] Guyomarc'h F., Formation of heat-induced protein aggregates in milk as a means to recover the whey protein fractionation in cheese manufacture, and potential of heattreating milk at alkaline $\mathrm{pH}$ values in order to keep its rennet coagulation properties. A review, Lait 86 (2006) 1-20.

[12] Jelen P., Rattray W., Thermal denaturation of whey proteins, in: Fox P.F. (Ed.), Heat Induced Changes in Milk, 2nd edn., International Dairy Federation, Brussels, Belgium, 1995, pp. 66-80.

[13] Jensen O.N., Larsen M.R., Roepstorff P., Mass spectrometric identification and microcharacterization of proteins from electrophoretic gels: strategies and applications, Proteins 2 (1998) 74-89.

[14] Kang D.H., Gho Y.S., Suh M.K., Kang C.H., Highly sensitive and fast protein detection with Coomassie brilliant blue in sodium dodecyl sulfate-polyacrylamide gel electrophoresis, Bull. Korean Chem. Soc. 23 (2002) 1511-1512.

[15] Kanno C., Purification and separation of multiple forms of lactophorin from bovine milk whey and their immunological and electrophoretic properties, J. Dairy Sci. 72 (1989) 883-891.

[16] Lametsch R., Bendixen E., Proteome analysis applied to meat science: characterizing post mortem changes in porcine muscle, J. Agric. Food Chem. 49 (2002) 4531-4537.

[17] Lametsch R., Roepstorff P., Bendixen E., Identification of protein degradation during post mortem storage of pig meat, J. Agric. Food Chem. 50 (2002) 5508-5512.
[18] Lindmark-Månsson H., Timgren A., Aldén G., Paulsson M., Two-dimensional gel electrophoresis of proteins and peptides in bovine milk, Int. Dairy J. 15 (2005) 111121

[19] Malin E.L., Brown E.M., Wickham E.D., Farrell H.M. Jr., Contributions of terminal peptides to the associative behaviour of $\alpha_{\mathrm{S}_{1}}$ casein, J. Dairy Sci. 88 (2005) 2318-2328.

[20] McSweeney P.L.H., Olson N.F., Fox P.F., Healy A., Proteolysis of bovine $\alpha_{\mathrm{S} 2}$-casein by chymosin, Z. Lebensm. Unters. Forsch. A 199 (1994) 429-432.

[21] McSweeney P.L.H., Olson N.F., Fox P.F., Healy A., Höjrup P., Proteolytic specificity of chymosin on bovine $\alpha_{\mathrm{S} 1}$-casein, J. Dairy Res. 60 (1993) 401-412.

[22] Neuhoff V., Arold N., Taube D., Eberhart W., Improved staining of proteins in polyacrylamide gels including isoelectric focusing gels with clear background at nanogram sensitivity using Coomassie Brilliant Blue G-250 and R-250, Electrophoresis 9 (1988) 255-262.

[23] O'Donnell R., Holland J.W., Deeth H.C., Alewood P., Milk proteomics. Review, Int. Dairy J. 14 (2004) 1013-1023.

[24] Paulsson M., Dejmek P., Thermal denaturation of whey proteins in mixtures with caseins studied by differential scanning calorimetry, J. Dairy Sci. 73 (1990) 590-600.

[25] Qi P.X., Wickham E.D., Farrell H.M. Jr., Thermal and alkaline denaturation of bovine $\beta$-casein, Protein J. 23 (2004) 389-402.

[26] Rasmussen L.K., Højrup P., Petersen T.E., Localization of two interchain disulfide bridges in dimers of bovine $\alpha_{\mathrm{S} 2}$-casein, Eur. J. Biochem. 203 (1992) 381-386.

[27] Rynne N.M., Beresford T.P., Kelly A.L., Guinee T.P., Effect of milk pasteurisation temperature and in situ whey protein denaturation on the composition, texture and heatinduced functionality of half-fat Cheddar cheese, Int. Dairy J. 14 (2004) 989-1001.

[28] Sørensen E.S., Petersen T.E., Phosphorylation, glycosylation and amino acid sequence of component PP3 from the proteose peptone fraction of bovine milk, J. Dairy Res. 60 (1993) 535-542.

[29] Sørensen E.S., Rasmussen L.K., Petersen T.E., The localization and multimeric nature of component PP3 in bovine milk: purification and characterization of PP3 from caprine and ovine milks, J. Dairy Sci. 80 (1997) 31763181 . 
[30] Walstra P., Wouters J.T.M., Geurts T.J., Dairy Science and Technology, Taylor and Francis, New York, USA, 1999.

[31] Wedholm A., Larsen L.B., LindmarkMånsson H., Karlsson A.H., Andrén A., Effect of protein composition on the cheese-making properties of milk from individual dairy cows, J. Dairy Sci. 89 (2006) 3296-3305.
[32] Wedholm A., Møller H.S., Stensballe A., Lindmark-Månsson H., Karlsson A.H., Andersson R., Andrén A., Larsen L.B., Effect of minor milk proteins in chymosin separated whey and casein fractions on cheese yield as determined by proteomics and multivariate data analysis, J. Dairy Sci. 91 (2008) 3787-3797. 